\title{
Evaluation of cottonseed bioactive peptides supplementation on performance, egg quality, and total antioxidant activity of serum in laying hens
}

\author{
Nasir Landy ${ }^{*}$ (i) and Farshid Kheiri
}

\begin{abstract}
Background: A study was undertaken to assess the effect of bioactive peptides derived from cottonseed (BPC) supplementation on productive performance, egg quality, and total antioxidant capacity (TAC) of serum and yolk in laying hens. A total of seventy-two 22-week-old Bovans White hens were randomly allocated to 12 cages to have similar cage body weight $(1520 \pm 5 \mathrm{~g})$. The dietary treatments consist of basal diet (control) and basal diet supplements with $5 \mathrm{~g} \mathrm{BPC} / \mathrm{kg}$ of diet. Recording data initiated after 2 weeks.

Results: In the second week, hens fed diets containing BPC had significantly higher egg mass and egg weight $(P<0.05)$. Final BW was significantly higher in laying hens fed diets containing BPC $(P<0.05)$. The percentage of egg white protein as one of the highest quality proteins available was significantly higher in laying hens fed diets supplemented with BPC $(P<0.05)$. Hens fed diets containing BPC had significantly higher TAC compared with control group $(P<0.05)$.
\end{abstract}

Conclusions: The results indicated that addition of BPC to Bovans White hens at peaking period, receiving nutrient adequate diets, could induce favorable influences on egg quality and TAC of egg.

Keywords: Bovans White, Bioactive peptides, Egg white protein, Egg mass. Health status

\section{Background}

Because of an enormous necessity for proper antibiotic growth promoters (AGP) alternative, probiotics (Mountzouris et al. 2007; Toghyani et al. 2015), prebiotics (Sarao and Arora, 2017), essential oils and natural products (Landy et al. 2011a; Shokraneh et al. 2016; Foroutankhah et al. 2019; Kheiri et al. 2018), and bioactive peptides (Jakubczyk et al. 220) have received remarkable consideration. Peptides are recently being further investigated because they have both nutritional and physiological or regulatory functions (Raveschot et al. 2018). Peptides

\footnotetext{
*Correspondence: n_landy1984@yahoo.com

Department of Animal Science, Shahrekord Branch, Islamic Azad University, 8813733395 Shahrekord, Iran
}

which are isolated from different protein sources and providing some in vitro and vivo physiological benefit effects are known bioactive peptides (Bhandari et el. 2020). Some peptides which are originated from plantsource feedstuffs or animal products showed antimicrobial (Bevins annd Salzman 2011), antioxidant (Bah et al. 2016; Power et al. 2013), antihypertensive (Bah et al. 2016), and immunomodulatory activities (Kotzamanis et al. 2007; Landy et al. 2021). Physiological function of bioactive peptides depends on their molecular weight and the sequence of amino acids in peptide (López-Barrios et al. 2014; Hou et al. 2017).

Abdollahi et al. (2017) reported that supplementation of bioactive peptides derived from soybean meal which produced by enzymatic hydrolysis (SBP) improved 
productive performance and feed conversion ratio (FCR) of broiler chickens. Similarly, addition of SBP in broiler diets could induce favorable influences on performance criteria (Abdollahi et al. 2018). Hisham et al. (2018) reported the ability of bioactive peptides derived from casein and whey to enhance the tolerance of yeast cells against peroxide-induced oxidative stress. Landy et al. (2020) investigated the potential of different levels of bioactive peptides derived from cottonseed (BPC) to enhance productive performance and health status of broiler chickens in comparison with an AGP and an antioxidant; the results indicated that addition of $5 \mathrm{~g} \mathrm{BPC} / \mathrm{kg}$ of diet can be used as an AGP substitution and it showed comparable antioxidant activity with positive control. Pan et al. (2019) reported that supplementation of laying hens diet with $5 \mathrm{~g} \mathrm{SBP} / \mathrm{kg}$ of diet could improve productive performance, and egg quality by promoting intestine morphology and digestibility of protein and fat.

At peaking period the percentage of egg production enhances very rapidly, although feed consumption does not enhance at a proportional rate. Olukosi et al. (2017) reported that addition of SBP to laying hens diets at peaking period did not enhance productive performance but affirmatively helped to sustain hens' body weight (BW) and egg quality during storage; unfortunately, they did not provide a reason for the obtained results during the storage; thus, the objective of this study was to investigate the effects of CBP supplementation to Bovans White hens diets at peak production on productive performance, egg quality, and total antioxidant capacity (TAC) of serum and yolk.

\section{Methods}

\section{Animals and dietary treatments}

The trial was performed in spring on Pishgam Damparvar Sepahan company research farm which is located in Esfahan Province. A total of seventy-two 22-week-old Bovans White hens were individually weighed and randomly allocated to 12 cages to have similar cage body weight $(1520 \pm 5 \mathrm{~g})$. Two dietary treatments were formulated to contain 0 (basal diet as a control) or $5 \mathrm{~g} \mathrm{BPC} / \mathrm{kg}$ of diet to meet the nutrient requirement of Bovans White hens (Bovans White Commercial Product Guide, North American Version) and were fed diets in mash form (Table 1). The dietary treatments were subjected to laying hens from 22 to 29 week of age, and egg recording started in the subsequent two weeks. Lighting program for laying house was set at $16 \mathrm{~L}: 8 \mathrm{D}$. For optimum bird health and performance, laying house temperature was kept at $26 \pm 2{ }^{\circ} \mathrm{C}$ and for optimum feather growth, health and feed efficiency relative humidity was kept at $55 \% \pm 2 \%$. Hens had free access to feed and water.
Table 1 Ingredients and calculated composition of experimental diets

\begin{tabular}{|c|c|c|}
\hline \multirow[b]{2}{*}{ Item } & \multicolumn{2}{|c|}{$\begin{array}{l}\text { Cottonseed } \\
\text { bioactive } \\
\text { peptide } \\
\text { inclusion (BPC; } \\
\mathrm{g} / \mathrm{kg} \text { ) }\end{array}$} \\
\hline & 0.0 & 5.0 \\
\hline \multicolumn{3}{|l|}{ Ingredients, g/kg (as-fed) } \\
\hline Corn $(7.5 \%$ CP) & 517.2 & 518.4 \\
\hline Soybean meal (44\% CP) & 273.8 & 268.5 \\
\hline Corn gluten meal (55.4\% CP) & 30.0 & 30.0 \\
\hline Cottonseed bioactive peptides (46\% CP) & 0.0 & 5.0 \\
\hline Wheat bran (14.9\% CP) & 10.0 & 9.5 \\
\hline Soybean oil & 43.8 & 43.7 \\
\hline DL-methionine & 2.4 & 2.4 \\
\hline L-lysine & 1.1 & 1.1 \\
\hline L-threonine & 0.3 & 0.3 \\
\hline Choline chloride & 0.3 & 0.3 \\
\hline Mono calcium phosphate (15\% Ca, 22.5\% P) & 16.3 & 16.3 \\
\hline Calcium carbonate & 98.3 & 98.0 \\
\hline Sodium chloride & 3.2 & 3.2 \\
\hline Sodium bicarbonate & 1.3 & 1.3 \\
\hline Trace mineral premix ${ }^{1}$ & 1 & 1 \\
\hline Vitamin premix ${ }^{2}$ & 1 & 1 \\
\hline \multicolumn{3}{|l|}{ Calculated composition, $\mathrm{g} / \mathrm{kg}$} \\
\hline Metabolizable energy, kcal/kg & 2,860 & 2,860 \\
\hline Crude protein & 180 & 180 \\
\hline Lysine & 9.8 & 9.8 \\
\hline Methionine & 2.81 & 2.78 \\
\hline Methionine + Cysteine & 8.2 & 8.2 \\
\hline Threonine & 7.0 & 7.0 \\
\hline Tryptophan & 2.0 & 2.1 \\
\hline Arginine & 11.2 & 11.3 \\
\hline Valine & 8.3 & 8.3 \\
\hline Isoleucine & 7.4 & 7.4 \\
\hline Calcium & 41.0 & 41.0 \\
\hline Available P & 4.5 & 4.5 \\
\hline Ether extract & 68.9 & 68.7 \\
\hline Linoleic acid & 31.5 & 31.5 \\
\hline Crude fiber & 26.6 & 26.3 \\
\hline \multicolumn{3}{|l|}{ Analyzed content, g/kg } \\
\hline Crude protein & 183 & 182 \\
\hline
\end{tabular}

${ }^{1}$ Provided the following per kilogram of diet: $\mathrm{Mg}, 85 \mathrm{mg} ; \mathrm{Fe}, 80 \mathrm{mg} ; \mathrm{Cu}, 10 \mathrm{mg}$; $\mathrm{Zn}, 80 \mathrm{mg} ; \mathrm{Se}, 0.3 \mathrm{mg} ; \mathrm{l}, 1.0 \mathrm{mg}$

${ }^{2}$ Provided the following per kilogram of diet: vitamin $A, 12,000 \mathrm{IU}$; vitamin $\mathrm{D}_{3}$, $3,000 \mathrm{IU}$; vitamin E,20 IU; vitamin K, $3.0 \mathrm{mg}$; thiamin, $2.2 \mathrm{mg}$; riboflavin, $6.5 \mathrm{mg}$; nicotinic acid, $40 \mathrm{mg}$; pantothenic acid, $10 \mathrm{mg}$; pyridoxine, $4.5 \mathrm{mg}$; biotin, $0.20 \mathrm{mg}$; folic acid, $1.0 \mathrm{mg}$; vitamin $\mathrm{B}_{12}, 0.02 \mathrm{mg}$

\section{Bioactive peptides derived from cottonseed and its analysis}

The peptide consumed in the present study was isolated from enzymatic hydrolysis of cottonseed. The 
operation to produce BPC is as follows. The dehulled solvent-extracted cottonseed meal (SCM) was sterilized at $105{ }^{\circ} \mathrm{C}$ for $30 \mathrm{~min}$ and cooled to $50{ }^{\circ} \mathrm{C}$ thereafter. Calcium hydroxide and alkaline protease were applied to hydrolyze SCM at $50{ }^{\circ} \mathrm{C}$ and $\mathrm{pH} 8.0-9.0$ for $10 \mathrm{~h}$. The obtained product was placed in drying ovens set at $90{ }^{\circ} \mathrm{C}$ for $12 \mathrm{~h}$ thereafter. Prior to formulating diets, maize, soybean meal, and BPC got the measure of crude protein levels by Method 990.03 of AOAC (2006) and the quantity of total amino acids by Methods $982.30 \mathrm{E}$ $a, b$, and c of AOAC (2006). The BPC got the measure of total phosphorus and calcium by inductively coupled plasma-optical emission spectrometry by Method 2011.14 of AOAC (1965) at the Laboratory of Shahrekord University Faculty of Agriculture (Table 2). As Jung et al. (2006) described the BPC took the measurement of molecular weight distribution by a Superdex peptide HR 10/30 column.

\section{Hen performance}

Egg weight, the number of egg produced, broken eggs, and mortality were recorded daily and reported

Table 2 Analysis of the protein hydrolysates of cottonseed

\begin{tabular}{ll}
\hline Composition of protein hydrolysates of cottonseed, $\mathbf{g} / \mathbf{k g}$ & \\
\hline Moisture & 80.0 \\
Ash & 150.0 \\
Crude fat & 25.0 \\
Crude fiber & 70.0 \\
Nitrogen-free extract & 210.6 \\
Total protein (N x 6.25) & 464.4 \\
Peptides with molecular weight <1000 Da & 180.0 \\
Arg & 41.2 \\
His & 12.0 \\
Ile & 16.0 \\
Leu & 26.2 \\
Lys & 30.6 \\
Met & 9.4 \\
Cys & 8.0 \\
Phe & 21.0 \\
Thr & 14.2 \\
Val & 19.5 \\
Gly & 17.3 \\
Ala & 17.5 \\
Pro & 22.7 \\
Ser & 23.5 \\
Asp & 58.5 \\
Glu & 93.0 \\
Tyr & 12.8 \\
Trp & 6.0 \\
Calcium & 33.0 \\
\hline & \\
\hline
\end{tabular}

weekly. Hen-day egg production, egg mass (g per hen daily), and the percentage of broken eggs were calculated. Means for average daily feed intake (ADFI) and FCR were determined at termination of the experiment (whole trial). BW was determined at day 1 , and termination of the experiment.

\section{Egg collection}

At the end of experiment, 12 eggs per replicate were collected, weighed, and allocated to three parts. Onethird of the eggs were applied for egg quality assessment. One-third of the eggs were used for TAC of yolk assessment, and one-third of them were used for eggshell strength.

\section{Egg quality}

Haugh unit, albumen height, egg yolk color, and height have been measured by a multi-tester (EMT-7300, Robotmation Co., Ltd., Tokyo, Japan). The albumen was separated from yolk, dried, and crude proteins in dried samples were measured by the Kjeldahl method (2005). The eggshell strength was determined via a digital egg tester (DET-6000, Nabel Co., Ltd., Kyoto, Japan), and eggshell thickness was determined via an eggshell thickness gauge (ESTG-1, Orka Food Technology Ltd., Ramat Hasharon, Israel) as the average of large end, equator, and small end using a vernier caliper.

\section{Total antioxidant capacity of serum and yolk}

At termination of the experiment, two blood samples per cage were obtained by puncture of brachial vein and serum samples were separated (12 samples per treatment). Egg yolks were separated from albumen and used to measure TAC. TAC was measured in samples by using BioAssay Systems Commercial kit (Re et al. 1999).

\section{Statistical analysis}

A one-way ANOVA was used to examine responses to addition of BPC to laying hen diets at peaking period in a completely randomized design. All data were analyzed by the general linear model (GLM) procedure of SPSS (SPSS Inc., Chicago, IL) software, and significance was accepted at $P<0.05$.

\section{Results}

\section{Productive performance}

The weekly egg production related parameters, broken eggs and the percentage of mortality are shown in Table 3. During the first week assessed parameters did not significantly affect by the dietary treatments 
Table 3 Performance response to peptide supplementation in different periods

\begin{tabular}{|c|c|c|c|c|c|}
\hline \multirow[t]{2}{*}{ Time (week) } & \multirow[t]{2}{*}{ Parameter } & \multicolumn{3}{|c|}{ Dietary treatments } & \multirow[t]{2}{*}{$P$ value } \\
\hline & & Control & $5 \mathrm{~g} \mathrm{BPC}^{*} / \mathrm{kg}$ & SEM $^{* *}$ & \\
\hline \multirow[t]{5}{*}{1} & $\begin{array}{l}\text { Egg mass (g per hen } \\
\text { daily) }\end{array}$ & 54.5 & 54.2 & 0.59 & 0.73 \\
\hline & Egg weight (g) & 58 & 58.03 & 0.62 & 0.97 \\
\hline & $\begin{array}{l}\text { Hen-day production } \\
(\%)\end{array}$ & 94 & 93.5 & 0.58 & 0.57 \\
\hline & Broken eggs (\%) & $0.1^{b}$ & $0.28^{\mathrm{a}}$ & 0.01 & 0.004 \\
\hline & Mortality (\%) & 0.07 & 0.06 & 0.00 & 0.48 \\
\hline \multirow[t]{5}{*}{2} & $\begin{array}{l}\text { Egg mass (g per hen } \\
\text { daily) }\end{array}$ & $51.86^{b}$ & $55.25^{\mathrm{a}}$ & 0.55 & 0.01 \\
\hline & Egg weight (g) & $55.06^{b}$ & $58.29^{\mathrm{a}}$ & 0.53 & 0.01 \\
\hline & $\begin{array}{l}\text { Hen-day production } \\
(\%)\end{array}$ & 94.19 & 94.8 & 0.65 & 0.49 \\
\hline & Broken eggs (\%) & 0.1 & 0.18 & 0.02 & 0.07 \\
\hline & Mortality (\%) & 0.05 & 0.05 & 0.65 & 1.00 \\
\hline \multirow[t]{5}{*}{3} & $\begin{array}{l}\text { Egg mass (g per hen } \\
\text { daily) }\end{array}$ & 55.22 & 55.7 & 1.15 & 0.78 \\
\hline & Egg weight (g) & 59.06 & 58.8 & 1.23 & 0.88 \\
\hline & $\begin{array}{l}\text { Hen-day production } \\
(\%)\end{array}$ & 93.5 & 94.7 & 1.18 & 0.50 \\
\hline & Broken eggs (\%) & $0.00^{b}$ & $0.12^{\mathrm{a}}$ & 0.00 & 0.001 \\
\hline & Mortality (\%) & 0.05 & 0.05 & 0.57 & 1.00 \\
\hline \multirow[t]{5}{*}{4} & $\begin{array}{l}\text { Egg mass (g per hen } \\
\text { daily) }\end{array}$ & 57.04 & 56.19 & 1.05 & 0.34 \\
\hline & Egg weight (g) & 59.92 & 59.4 & 0.57 & 0.55 \\
\hline & $\begin{array}{l}\text { Hen-day production } \\
(\%)\end{array}$ & 95.19 & 94.58 & 1.47 & 0.78 \\
\hline & Broken eggs (\%) & 0.1 & 0.15 & 0.02 & 0.28 \\
\hline & Mortality (\%) & 0.06 & 0.06 & 0.00 & 1.00 \\
\hline \multirow[t]{5}{*}{5} & $\begin{array}{l}\text { Egg mass (g per hen } \\
\text { daily) }\end{array}$ & 57.28 & 57.4 & 1.15 & 0.94 \\
\hline & Egg weight (g) & 59.93 & 59.52 & 0.57 & 0.64 \\
\hline & $\begin{array}{l}\text { Hen-day production } \\
(\%)\end{array}$ & 95.57 & 96.44 & 1.15 & 0.62 \\
\hline & Broken eggs (\%) & 0.07 & 0.21 & 0.04 & 0.07 \\
\hline & Mortality (\%) & 0.06 & 0.05 & 0.57 & 0.28 \\
\hline
\end{tabular}

${ }^{*}$ Cottonseed bioactive peptide. ${ }^{* *}$ Standard error of mean. ${ }^{\mathrm{a}-\mathrm{b}}$ Values in the same row not sharing a common superscript differ $P<0.05$

$(P>0.05)$. In the second week egg mass (g per hen daily) and egg weigh were significantly higher $(P<0.05)$ in laying hens fed BPC. During week 3, the percentage of broken eggs was significantly higher in laying hens fed diets supplemented with BPC $(P<0.05)$. During week 4 and 5 dietary BPC supplementation did not significantly affect assessed parameters $(P>0.05)$. Productive performance responses to peptide supplementation in the whole trial are presented in Table 4. Performance criteria were not affected by the dietary treatments except for final BW which was significantly higher in laying hens fed diets containing BPC $(P<0.05)$.

\section{Egg quality parameters}

Egg quality-related parameters are presented in Table 5. Haugh units were not markedly affected by the dietary treatments $(P>0.05)$. Albumen height, yolk color, yolk height, and eggshell thickness were not markedly affected by the dietary treatments $(P>0.05)$. The percentage of protein in albumen was significantly higher in laying hens fed diets supplemented with BPC $(P>0.05)$.

\section{Antioxidant status}

Table 6 illustrates TAC in serum and yolk. The TAC of were not significantly affected by the dietary treatments 
Table 4 Effect of cotton seed bioactive peptides supplementation on the body weight, food consumption, and food conversion efficiency of laying hens

\begin{tabular}{|c|c|c|c|c|c|}
\hline & \multirow[t]{2}{*}{ Item } & \multicolumn{2}{|c|}{ Dietary treatments } & \multirow[t]{2}{*}{ SEM $^{* *}$} & \multirow[t]{2}{*}{$P$ value } \\
\hline & & Control & $5 \mathrm{~g} \mathrm{BPC}^{*} / \mathbf{k g}$ & & \\
\hline \multirow[t]{5}{*}{ Whole trial } & Egg mass (g per hen daily) & 54.83 & 55.24 & 0.57 & 0.64 \\
\hline & ADFI (g) & 106 & 107 & 1.15 & 0.57 \\
\hline & FCR (feed/gain) & 1.93 & 1.93 & 0.05 & 1.00 \\
\hline & Final body weight (g) & $1622^{b}$ & $1644^{\mathrm{a}}$ & 5.77 & 0.05 \\
\hline & Body weight gain (g/d) & $2.14^{\mathrm{b}}$ & $2.55^{\mathrm{a}}$ & 0.12 & 0.04 \\
\hline
\end{tabular}

${ }^{*}$ Cottonseed bioactive peptide. ${ }^{* *}$ Standard error of mean. ${ }^{a-b}$ Values in the same row not sharing a common superscript differ $P<0.05$. ADFI, average daily feed intake; FCR, feed conversion ratio

Table 5 The effects of dietary treatments on quality of the eggs

\begin{tabular}{lcccc}
\hline \multirow{2}{*}{ Item } & \multicolumn{2}{c}{ Dietary treatments } & SEM $^{* *}$ & P value \\
\cline { 2 - 4 } & Control & $\mathbf{5 ~ g ~ B P C} \mathbf{~ k g ~}$ & & \\
\hline Haugh unit & 96.5 & 94.8 & 1.23 & 0.33 \\
Protein in albumen (\%) & $10.5^{\mathrm{b}}$ & $11.4^{\mathrm{a}}$ & 0.16 & 0.001 \\
Albumen height (mm) & 6.54 & 6.58 & 0.15 & 0.82 \\
Yolk color & 10.9 & 11.4 & 0.34 & 0.35 \\
Yolk height (mm) & 18.56 & 18.33 & 0.19 & 0.39 \\
Eggshell Thickness (MM) & 0.42 & 0.41 & 0.00 & 0.09 \\
Eggshell strength(kg/cm2) & 3.88 & 4.04 & 0.16 & 0.48 \\
\hline
\end{tabular}

${ }^{*}$ Cottonseed bioactive peptide. ${ }^{* *}$ Standard error of mean. ${ }^{\mathrm{a}-\mathrm{b}}$ Values in the same row not sharing a common superscript differ $P<0.05$

Table 6 Influence of dietary treatments on antioxidant status of laying hens

\begin{tabular}{|c|c|c|c|c|}
\hline \multirow[b]{2}{*}{ Item } & \multicolumn{2}{|c|}{ Dietary treatments } & \multirow[b]{2}{*}{ SEM $^{* *}$} & \multirow[b]{2}{*}{$P$ value } \\
\hline & Control & $5 \mathrm{~g} \mathrm{BPC}^{*} / \mathrm{kg}$ & & \\
\hline $\mathrm{TAC}^{\mathrm{C}}$ of serum, $\mu \mathrm{M}$ & 1617 & 1756 & 73 & 0.17 \\
\hline TAC of yolk, $\mu \mathrm{M}$ & $1342^{b}$ & $2225^{\mathrm{a}}$ & 192 & 0.008 \\
\hline
\end{tabular}

${ }^{*}$ Cottonseed bioactive peptide. ${ }^{* *}$ Standard error of mean. ${ }^{~}$ Total antioxidant capacity expressed as $\mu$ M Trolox Equivalents. ${ }^{a-b}$ Values in the same row not sharing a common superscript differ $P<0.05$

$(P>0.05)$. TAC of yolk was significantly higher in laying hens supplemented with BPC $(P<0.05)$.

\section{Discussion}

In the present study the body weight gain was significantly higher in the group supplemented with BPC. Similarly, Olukosi et al. (2017) reported that supplementation of SBP had not any significant effect on FCR and ADFI, but its supplementation significantly increased final BW of laying hens. In the present study, in the second week egg mass and egg weigh were markedly higher in laying hens fed BPC. Pan et al. (2019) reported that addition of SBP to nutrient deficiency diet improved productive performance, intestinal morphology, and apparent availability of crude protein and ether extract in diet. Abdollahi et al. (2017) reported that supplementation of SBP enhanced villus height, and its utilization improved digestibility of dry matter and nitrogen. Feng et al. (2007) reported that addition of fermented soybean meal in broiler diets could enhance the activation of proteases enzymes. Similarly, Caspary (1992) reported an increment in digestive, absorptive functions, and expression of brush border enzymes. Since the egg mass production is very effectively correlated with the level and digestibility of protein, so the observed results in the current experiment may be due to an enhancement in protein digestibility. On the other hand, although apparent differences were seen in egg mass and egg weight, the corresponding increase in broken eggs in the treatment group may reduce the potential benefits of $\mathrm{BPC}$ supplementation. The occurrence of broken eggs depends on different parameters such as adequate nutrition, disease control, and good management practices. Since, given a round shape, an enhancement in egg weight and size results in a greater enhancement of the surface area, higher levels of calcium are required to maintain egg shell quality. As regards, in the present study the level of calcium in two groups was similar; hence, the higher percentage of broken egg may be related to the level of calcium.

In the current trial, the percentage of egg white protein as one of the highest quality proteins available was significantly higher in laying hens fed diets supplemented with BPC. In contrast with our results, Pan et al. (2019) reported that supplementation of SBP in laying hen diet had significant effects on albumen height and Haugh unit. Olukosi et al. (2017) investigated the effects of SBP supplementation on internal egg quality at collection, 4 week and 8 week after collection; they reported that it takes longer than 4 weeks for the peptide to exert its effect on egg quality. 
In the current study, protein in albumen significantly increased by BPC supplementation. According to Novak et al. (2006) report egg albumen quality is very effectively dependent with quality of protein in the diet.

TAC of yolk was significantly higher in laying hens supplemented with BPC. Similarly, Landy et al. (2020) reported that supplementation of $5 \mathrm{~g} \mathrm{BPC} / \mathrm{kg}$ of diet significantly enhanced TAC of serum in broiler chickens. TAC consists of a group of antioxidant enzymes and the correlated very complicated biomolecules in scavenging free radicals (2012). Girgih et al. (2015) reported that peptides containing high amount of aromatic amino acids (AA) have the ability to cleave the oxidation chain reaction. Bioactive peptides which have the radical scavenging activity are known as peptides with high amount of hydrophobic AA residues (Davalos et al. 2004). Since BPC contains high amount of hydrophobic AA, the obtained results may be correlated with AA sequence of BPC.

\section{Conclusions}

The results indicated that addition of BPC to Bovans White hens at peaking period, receiving nutrient adequate diets, could induce favorable influences on egg quality and TAC of egg; thus, it can be expected that higher TAC in the egg can help to extend egg shelf life at room temperature. In the second week, hens fed diets containing BPC had significantly higher egg mass and egg weight. Furthermore, BPC supplementation helped the hens to maintain their BW at peaking period, and thus, its probable effects on productive performance must be further investigated. Further investigations are needed to determine factors which are related to higher percentage of broken eggs when BPC are supplemented to adequate diets.

\begin{abstract}
Abbreviations
AGP: Antibiotic growth promoters; SBP: Bioactive peptides derived from soybean meal; FCR: Feed conversion ratio; BPC: Bioactive peptides derived from cottonseed; BW: Body weight; TAC: Total antioxidant capacity; SCM: Solventextracted cottonseed meal; ADFI: Average daily feed intake.
\end{abstract}

\section{Acknowledgements}

The authors thank Pishgam Damparvar Sepahan Co. Ltd for supplying hen house, feed, and skill workers.

\section{Authors' contributions}

$\mathrm{NL}$ and FKH designed the experiment. NL conducted the experiment, statistical analysis, and interpretation of field data. NL wrote the manuscript. All authors read and approved the final manuscript.

\section{Funding}

There was no funding for this research.

\section{Availability of data and materials}

Authors are willing to share all data used in the experiment upon a written request to corresponding author.

\section{Declarations}

Ethics approval and consent to participate

All trial procedures were approved by the ethical guidelines of the Animal Care and Welfare Committee of the Islamic Azad University, Shahrekord Branch (approval ref no. 2020-033).

\section{Consent for publication}

Not applicable.

\section{Competing interests}

The authors declare that they have not competing interest.

Received: 23 September 2021 Accepted: 22 October 2021

Published online: 30 October 2021

\section{References}

Abdollahi MR, Zaefarian F, Gu Y, Xiao W, Jia J, Ravindran V (2017) Influence of soybean bioactive peptides on growth performance, nutrient utilisation, digestive tract development and intestinal histology in broilers. J Appl Anim Nutr 5:1-7

Abdollahi MR, Zaefarian F, Gu Y, Xiao W, Jia J, Ravindran V (2018) Influence of soybean bioactive peptides on performance, foot pad lesions and carcass characteristics in broilers. J Appl Anim Nutr 6:1-7

AOAC (1965) Official methods of analysis, 10th edn. AOAC, Washington (DC) AOAC (2006) Official methods of analysis, 18th edn. AOAC, Washington (DC) AOAC. 2005. Official methods of analysis. 18th ed. Arlington, (VA): AOAC.

Bah CS, Carne A, McConnell MA, Mros S, Bekhit A-D (2016) Production of bioactive peptide hydrolysates from deer, sheep, pig and cattle red blood cell fractions using plant and fungal protease preparations. Food Chem 202:458-466

Bevins CL, Salzman NH (2011) Paneth cells, antimicrobial peptides and maintenance of intestinal homeostasis. Nature Rev Microbiol 9:356-368

Bhandari D, Rafiq S, Gat Y, Gat P, Waghmare R, Kumar V (2020) A review on bioactive peptides: physiological functions, bioavailability and safety. Int J Pept Res Ther 26:139-150

Caspary WF (1992) Physiology and pathophysiology of intestinal absorption. Am J Clin Nutr 55:299S-308S

Davalos A, Miguel M, Bartolome B, Lopez-Fandino R (2004) Antioxidant activity of peptides derived from egg white proteins by enzymatic hydrolysis. J Food Prot 67:1939-1944

Feng J, Liu X, Xu ZR, Wang YZ, Liu JX (2007) Effects of fermented soybean meal on digestive enzyme activities and intestinal morphology in broilers. Poult Sci 86:1149-1154

Foroutankhah M, Toghyani M, Landy N (2019) Evaluation of Calendula officinalis L. (marigold) flower as a natural growth promoter in comparison with an antibiotic growth promoter on growth performance, carcass traits and humoral immune responses of broilers. Anim Nutr 5:314-318

Girgih AT, He R, Hasan FM, Udenigwe CC, Gill TA, Aluko RE (2015) Evaluation of the in vitro antioxidant properties of a cod (Gadus morhua) protein hydrolysate and peptide fractions. Food Chem 173:652-659

Hisham RI, Isono H, Miyata T (2018) Potential antioxidant bioactive peptides from camel milk proteins. Anim Nutr 4:273-280

Hou Y, Wu ZH, Dai ZH, Wang G, Wu G (2017) Protein hydrolysates in animal nutrition: Industrial production, bioactive peptides, and functional significance. J Anim Sci Biotechno 8:24

Jakubczyk A, Karás M, Rybczỳnska-Tkaczyk K, Zielínska E, Zielínski D (2020) Current trends of bioactive peptides-New sources and therapeutic effect. Foods 9:846

Kheiri F, Faghani M, Landy N (2018) Evaluation of thyme and ajwain as antibiotic growth promoter substitutions on growth performance, carcass characteristics and serum biochemistry in Japanese quails (Coturnix japonica). Anim Nutr 4:79-83

Kotzamanis YP, Gisbert E, Gatesoupe FJ, Zambonino Infante J, Cahu C (2007) Effects of different dietary levels of fish protein hydrolysates on growth, digestive enzymes, gut microbiota, and resistance to Vibrio anguillarum in European sea bass (Dicentrarchus labrax) larvae. Comp Biochem Physiol A 147:205-214 
Landy N, Kheiri f, Faghani M, (2021) Effects of periodical application of bioactive peptides derived from cottonseed on performance, immunity, total antioxidant activity of serum and intestinal development of broilers. Anim Nutr 7:134-141

Landy N, Ghalamkari GH, Toghyani M (2011) Performance, carcass characteristics, and immunity in broiler chickens fed dietary neem (Azadirachta indica) as alternative for an antibiotic growth promoter. Livest Sci 142:305-309

Landy N, Kheiri F, Faghani M (2020) Evaluation of cottonseed bioactive peptides on growth performance, carcase traits, immunity, total antioxidant activity of serum and intestinal morphology in broiler chickens. Ital J Anim Sci 19:1375-1386

López-Barrios L, Gutiérrez-Uribe JA, Serna-Saldívar SO (2014) Bioactive peptides and hydrolysates from pulses and their potential use as functional ingredients. J Food Sci 79:R273-R283

Mountzouris KC, Tsirtsikos P, Kalamara E, Nitsch S, Schatzmayr G, Fegeros K (2007) Evaluation of the efficacy of a probiotic containing Lactobacillus, Bifidobacterium, Enterococcus, and Pediococcus strains in promoting broiler performance and modulating cecal microflora composition and metabolic activities. Poult Sci 86:309-317

Novak C, Yakout HM, Scheideler SE (2006) The effect of dietary protein level and total sulfur amino acid:lysine ratio on egg production parameters and egg yield in Hy-Line hens. Poult Sci 85:2195-2206

Olukosi O, Xiao W, Jia J (2017) Peptide supplementation to nutrient-adequate diets enhanced internal egg quality during storage in hens at peak production. J Sci Food Agric

Pan L, Jianping W, Shiping B, Qiufeng Z, Xuemei D, Keing Z (2019) Effects of different nutrient level diets supplemented with enzymolytic soybean meal on performance, egg quality, nutrient apparent availability, and intestinal morphology of laying hen. Chi j Anim Nutr 31:1127-1137

Power O, Jakeman P, FitzGerald RJ (2013) Antioxidative peptides: enzymatic production, in vitro and in vivo antioxidant activity and potential applications of milk-derived antioxidative peptides. Amino Acids 44:797-820

Raveschot C, Cudennec B, Coutte F, Flahaut C, Fremont M, Drider D, Dhulster P (2018) Production of bioactive peptides by Lactobacillus species: from gene to application front. Microbiology 9:2354

Re R, Pellegrini N, Proteggente A, Pannala A, Yang M, Rice-Evans C (1999) Antioxidant activity applying an improved ABTS radical cation decolorization assay. Free Radic Biol Med 26:1231-1237

Ren WK, Yin YL, Liu G, Yu XL, Li YH, Yang G, Li TJ, Wu GY (2012) Effect of dietary arginine supplementation on reproductive performance of mice with porcine circovirus type 2 infection. Amino Acids 42:2089-2094

Sarao LK, Arora M (2017) Probiotics, prebiotics, and microencapsulation: a review. Crit Rev Food Sci Nutr 57:344-371

Shokraneh M, Ghalamkari GH, Toghyani M, Landy N (2016) Influence of drinking water containing Aloe vera (Aloe barbadensis Miller) gel on growth performance, intestinal microflora, and humoral immune responses of broilers. Vet World 9:1197-1203

Toghyani M, Mosavi SK, Modaresi M, Landy N (2015) Evaluation of kefir as a potential probiotic on growth performance, serum biochemistry and immune responses in broiler chicks. Anim Nutr 1:305-309

\section{Publisher's Note}

Springer Nature remains neutral with regard to jurisdictional claims in published maps and institutional affiliations.

\section{Submit your manuscript to a SpringerOpen ${ }^{\circ}$ journal and benefit from:}

- Convenient online submission

- Rigorous peer review

- Open access: articles freely available online

- High visibility within the field

- Retaining the copyright to your article

Submit your next manuscript at $\boldsymbol{\nabla}$ springeropen.com 